\title{
Regional Economic Integration and Exports Performance in the COMESA Region (1980-2012)
}

\author{
Henry Tumwebaze Karamuriro \\ Department of Economics and Statistics, Kyambogo University, Kyambogo, Kampala, Uganda
}

Email address:

htumwebaze@kyu.ac.ug

To cite this article:

Henry Tumwebaze Karamuriro. Regional Economic Integration and Exports Performance in the COMESA Region (1980-2012). International Journal of Business and Economics Research. Vol. 4, No. 1, 2015, pp. 11-20. doi: 10.11648/j.ijber.20150401.12

\begin{abstract}
One of the major development challenges facing Africa has been the small and fragmented economies with low incomes and low level of intra-regional exports. In an effort to promote intra-regional exports, Africa has witnessed renewed momentum for regional integration. This study examines the effect of regional economic integration on exports in the COMESA region. It employs the fixed effects regression, random effects regression and instrumental variables GMM regression to estimate an augmented trade gravity model using panel data from 1980 to 2012. The study results show that the formation of COMESA trading bloc has promoted intra-regional exports, implying intra-COMESA export bias. Comparing pre-COMESA (1980-1993) and post-COMESA (1994-2012) periods, it was found that intra-COMESA exports have grown by approximately 35 percent since COMESA was formed. This suggests that in order to enhance export flows in the region, the process of economic integration should be deepened. Thus, there is need for increased investment in transport infrastructure that will reduce long distance cost of doing business. This would have a major impact on deepening integration of COMESA economies.
\end{abstract}

Keywords: Regional Economic Integration, Exports, Gravity Model, Instrumental Variables GMM Regression

\section{Introduction}

A key development challenge facing Africa has been the small and fragmented economies with low incomes. In 2012 the average real per capita income in Africa was only US\$ 688 and 29 countries out of 53 in Africa were classified as low income countries with gross national income per capita of US\$ 995 or less (World Bank, 2013). Low incomes limit the size of Africa's domestic markets. The small domestic markets, in turn, translate into low economies of scale in production and low productivity for many African economies. In terms of exports, Africa has been characterized by a relatively low level of intra-regional trade. Trade data shows that on average over the past three decades, intra-African trade has been about 10 per cent compared to 60 per cent, 40 per cent, 30 per cent intra-regional trade achieved by Europe, North America and Asia respectively (African Union, 2012). Consequently, African countries have not been able to fully harness the complementarities of their economies and take full advantage of the economies of scale and other benefits such as income and employment generation.

In an attempt to promote intra-regional exports, Africa has witnessed renewed momentum for regional economic integration. The Common Market for Eastern and Southern Africa (COMESA) ${ }^{1}$ is one of the Regional Trading Agreements (RTAs) in Africa. It was formed to promote intra-regional exports among member states with the ultimate objective of creating more wealth and more incomes for the people of the region (COMESA Treaty, 1993). The expectation was that, by progressively dismantling trade barriers among the countries that make up COMESA, exports in the region would be enhanced through increased competition and a bigger population. Increased exports would ultimately foster economic growth and development of the member countries.

COMESA traces its genesis to the mid-1960s, when the countries of Eastern and Southern Africa initiated a process towards creating an Eastern and Southern African co-operation arrangement. This was after the post-colonial African leaders had envisaged that the small size and

1 COMESA trading bloc is made up of 19 countries, which include Burundi, Comoros, Congo D.R., Djibouti, Egypt, Eritrea, Ethiopia, Kenya, Libya, Madagascar, Malawi, Mauritius, Rwanda, Seychelles, Sudan, Swaziland, Uganda, Zambia and Zimbabwe. 
fragmentation of post-colonial African national economies would be a major constraint to economic development. In 1965, during the ministerial meeting of the United Nations Economic Commission for Africa (UNECA) held in Lusaka, Zambia, the creation of an Economic Community of Eastern and Southern African states was recommended.

In 1981, a treaty establishing the Preferential Trade Area for Eastern and Southern Africa (PTA) was signed, which entered into force in 1982. The PTA Treaty envisaged the eventual transformation of the PTA arrangement into a common market. Subsequently, the treaty establishing COMESA was signed in 1993 in Kampala, Uganda and was ratified a year later in Lilongwe, Malawi in 1994. It transformed into a Free Trade Area (FTA) ${ }^{2}$ in 2000. The COMESA Customs Union was launched in 2009 in Harare, Zimbabwe.

The forward agenda of COMESA includes steps currently underway towards negotiating an agreement on trade in services, and plans for the establishment of a Common Market in 2015, a Monetary Union in 2018 and later-on a COMESA community by 2025 . In 2025, COMESA expects to be a single trade and investment area in which tariffs, non-tariffs and other impediments to the movement of goods, services, capital and people will not be in existence, while trade in goods and services from the region will have achieved global market competitiveness (COMESA, 2011).

COMESA is also actively engaged in the COMESA-EAC-SADC tripartite process to build a Tripartite FTA and promote regional trade covering 26 countries, almost half of Africa. This is motivated by the current overlap of membership among COMESA, Southern African Development Community (SADC), and the East African Community (EAC). Out of the 19 members of COMESA, seven are members of SADC and four are members of EAC. ${ }^{3}$

Despite the existence of COMESA for the past two decades, its impact on exports of the member countries is not clear. Most of the member countries have been experiencing low rates of growth in exports, leading to an ever increasing trade deficit.

\section{Literature Review and Theoretical Framework}

\subsection{Empirical Evidence}

Previous empirical studies done on various regional integration schemes give mixed results. Some studies have found a positive correlation between regional economic integration and exports performance (Ajayi, 2005; Carrère, 2004; Musila, 2005). Other studies have found little or no empirical evidence to support a correlation between the two (Avom, 2005; Carrillo-Tudela \& Li, 2004; Elbadawi, 1995;

2 Members of the FTA include Burundi, Comoros, Djibouti, Egypt, Kenya, Libya, Madagascar, Malawi, Mauritius, Rwanda, Sudan, Swaziland, Zambia, and Zimbabwe.

3 COMESA/SADC members are DRC, Malawi, Mauritius, Seychelles, Swaziland, Zambia, and Zimbabwe. COMESA/EAC members are Burundi, Kenya, Rwanda and Uganda.
Jebuni, 1997; Kagira, 2001; Longo \& Sekkat, 2004; Ogunkola, 1998). Considering the period 1962-1996 within the framework of an augmented gravity model, Carrère (2004) used the Hausman-Taylor (1981) approach and showed that African regional trade agreements generated significant exports growth between member countries. For the particular case of the Franc zone, the study revealed that monetary unions (UEMOA and CEMAC) had largely reinforced the positive effect of the preferential trade agreements on intra-regional exports.

Ajayi (2005), who reviewed the process of economic integration in West Africa, found that participation in the Economic Community of West African States (ECOWAS) preferential trade agreement appeared to have increased exports among the member countries. However, the challenges of political instability, maintaining fiscal resources, and finding a suitable monetary unit presented considerable concerns for the creation of a single West African Union. Musila (2005) used the gravity model to estimate the intensity of trade creation or trade diversion in COMESA, CEEAC and ECOWAS. Using annual data for the years 1991 to 1998, this study found that the intensity of trade creation or trade diversion varied from region to region and from period to period. Indeed, empirical results showed that the intensity of trade creation was strongest in ECOWAS countries, followed by those in the COMESA area. The effect of trade creation in the CEEAC area was not empirically corroborated. The estimated results also suggest that the effects of trade diversion were weak in the three regional organizations.

However, other studies done on regional trading blocs in Africa have generally concluded that the experience of economic integration in Africa has been a failure in respect of increasing exports among member countries (Elbadawi, 1995; Forouton, 1992; Robson, 1998). Forouton (1992), who studied the effect of regional integration in Sub-Saharan Africa, concluded that the structural characteristics of the Sub-Saharan Africa economies, the pursuit of import-substitution policies, and the very uneven distribution of costs and benefits of integration arising from economic differences among the partner countries, had prevented any meaningful trade integration in the region. Of the seven or eight groupings in SSA, only SACU had achieved any noticeable degree of integration in the market for goods. Otherwise intra-group exports had remained limited and stagnant.

From a sample of 28 countries in Sub-Saharan Africa and 62 other countries as their trade partners over two subperiods (1980-1984 and 1986-1990), Elbadawi (1995) observed that the experiences of regional integration in Sub-Saharan Africa had been a failure. He also concluded that the two monetary unions, CEAO and UDEAC, and especially CEAO, experienced extremes of performance given that the effects of the trade integration scheme on intra- and inter-regional exports were positive during the first subperiod but negative during the second. According to Jebuni (1997), full trade liberalization is a more useful trade policy than merely engaging in preferential trade agreements. In his comparative 
study on trade liberalization and regional integration in Africa, he argued that regional trade integration may be difficult to enforce since it may lead to losses in government tariff revenues and instability in the balance of payments. $\mathrm{He}$ observed that African countries usually face high transportation costs for intra-regional exports compared to the costs involved in trade relations with industrialized countries. Finally, he concluded that these factors undermine the arguments in favour of trade integration in Sub-Saharan Africa.

In the case of ECOWAS, Ogunkola (1998) carried out a comparative analysis of the determinants of subregional exports by considering a pre-integration period (1970-1972) and a post-integration period (1978-1980). It transpires from the study's estimation results that the intra-ECOWAS exports remained very weak in spite of the integration efforts in the subregion during the two periods considered. Kagira (2001) examined the effects of regional integration on the performance of intra-industry trade in Eastern and Southern Africa. The PTA Treaty specified eight groups of non-tariff barriers (NTBs) that had to be relaxed and eventually eliminated. These included quantitative restrictions, export and import licensing, foreign exchange allocation, stipulation of import sources, prohibition of advance import deposits, conditional permission for imports, and special charges for acquiring foreign exchange. By 1992, significant progress had been made in relaxation of these NTBs. Despite these efforts, the success of integration programmes in terms of increased exports among the COMESA member states had been at its best marginal.

According to empirical studies done by Carrillo-Tudela and $\mathrm{Li}$ (2004), most regional trading blocs in Africa are faced with the problems of regional imbalance, price variations, open competition, language barriers, political hostilities, inconsistent customs regulations, and differences in internal tariffs. These factors have limited the success of regional integration initiatives in Sub-Saharan Africa. Similar results were obtained by Longo and Sekkat (2004), who revealed that the different integration schemes did not produce effects of trade creation or trade diversion and therefore were not able to lead to a growth in intra-African exports. Finally, Avom (2005) found that the impact of monetary union on exports inside CEMAC was not significant.

\subsection{Theoretical Framework of the Trade Gravity Model}

To assess the effect of COMESA RTA on intra-regional exports, the gravity model of international trade ${ }^{4}$ was used because of its considerable empirical robustness and explanatory power. Tinbergen (1962) and Pöyhönen (1963) were the first authors to apply the gravity model to analyze

4 The trade gravity model was adapted from Newton's Law of Universal Gravitation. Newton's theory postulates that the force of attraction between entities, say $i$ and $j$, is positively related to the entities' respective masses and inversely related to the square of the distance between the objects. It is expressed as $F_{i j}=\frac{G M_{i} M_{j}}{D_{i j}^{2}}$; where $F$ is the gravitational force, $M$ is mass, $D$ is distance, and $G$ is the gravitational constant. international trade flows. Since then, the gravity model has become a popular instrument in empirical foreign trade analysis. It has been extensively used for assessing trade policy implications and, particularly recently, for analyzing the effects of RTAs on trade. According to this model, trade flows can be explained by factors that capture the potential of a country to produce and export goods and services, the propensity of a country to import goods and services and factors that either attract or inhibit trade.

The basic gravity model of international trade is represented as;

$$
X_{i j}=\frac{K Y_{i}^{\alpha} Y_{j}^{\beta}}{D_{i j}^{\theta}}
$$

From Equation 3.1, $X_{i j}$ denotes the value of exports between countries $i$ and $j, Y$ is economic size (value of nominal GDP), $D_{i j}$ is the physical distance between the economic centres of countries $i$ and $j, K$ is the gravitational constant, while $\alpha, \beta$ and $\theta$ are parameters, and a priori signs of $\alpha$ and $\beta$ are positive while $\theta$ is negative.

Equation 3.1 can be converted into log-linear form as:

$$
\ln X_{i j}=\ln K+\alpha \ln Y_{i}+\beta \ln Y_{j}-\theta \ln D_{i j}+\delta Z+\varepsilon
$$

From Equation 3.2, $\delta \mathrm{Z}$ denotes other factors that may positively or negatively affect export flows, while $\varepsilon$ is the stochastic term.

Equation 3.2 implies that exports are positively affected by the economic mass of the trading partners and inversely related to the distance between them. However, additional variables, such as population, indicators of cultural affinity, and sharing of boarders are usually added to empirical gravity models to elaborate on the economic mass and distance variables (Clarete, Edmonds \& Wallack, 2002).

Hence, the augmented gravity model can be specified as:

$$
X_{i j}=\beta_{0} Y_{i}^{\beta_{1}} Y_{j}^{\beta_{2}} N_{i}^{\beta_{3}} N_{j}^{\beta_{4}} D_{i j}^{\beta_{5}} A_{i j}^{\beta_{6}} e^{y m} e^{u_{i j}}
$$

From Equation 3.3, $X_{i j}$ is the value of exports between pairs of countries, $Y_{i}\left(Y_{j}\right)$ represents the value of nominal GDP of the exporter (importer), $N_{i}\left(N_{j}\right)$ is the population of the exporter (importer), $D_{i j}$ is the physical distance between the economic centers of the two countries, $A_{i j}$ represents other factors that could aid or impede exports between countries, $e^{y m}$ is a vector of dummy variables that test for specific effects, and $e^{u_{i j}}$ is the error term.

A higher GDP signifies greater potential supply from the exporting country and increased demand in the importing country, leading to a positive effect on exports. The impact of the size of the population on exports can be positive or negative depending on whether the economies of scale effect 
is bigger than the absorption effect. Distance increases transport costs thereby impeding the flow of exports across countries.

\subsection{Theoretical Justification of the Gravity Model}

The application of the trade gravity model has sometimes been controversial, with critics arguing that the model lacks a coherent theoretical foundation. They believe that due to lack of a strong theoretical foundation, the estimated results of empirical gravity equations suffer omitted variable bias. Hence the estimates obtained from the gravity model cannot be validly used to draw conclusions about the determinants of trade flows. This is the motivation for the theoretical justification of the gravity model.

The first justification of the gravity model is Newton's Law of Universal Gravitation of 1687 . Newton's law was originally applied in physics, but has since spread to a whole range of social interactions, including trade, migration, tourism, and direct foreign investments. Based on this law, Tinbergen (1962) and Pöyhönen (1963) proposed that roughly the same functional form could be applied to international trade flows. Hence, they predicted that export flows between two countries are positively related to the economic sizes of the two countries and negatively related to the geographical distance between them.

Another justification of the gravity equation can be traced from the partial equilibrium model of export supply and import demand proposed by Linneman (1966). Basing on some simplifying assumptions, the gravity equation proves to be a reduced form of this partial equilibrium model. ${ }^{5}$ Linneman also expanded the gravity model by including the population variable to capture economies of scale and used the gross national product as an explanatory variable for the propensity to import.

Anderson (1979) provides another theoretical justification for the gravity equation based on the properties of expenditure systems. ${ }^{6}$ He also made the first formal attempt to derive the gravity equation from a model that assumed product differentiation. Helpman and Krugman (1985) used a differentiated product framework with increasing returns to scale to justify the gravity model. Bergstrand $(1985,1989)$ explored the theoretical determination of bilateral trade in a series of papers in which gravity equations were associated with simple monopolistic competition models.

Deardorff (1998), Anderson and Van Wincoop (2003), and Evenett and Keller (1998) have also contributed to improvements of the theoretical foundation of the gravity model. In these studies, the gravity equation is derived

\footnotetext{
5 According to this trade flow model, the potential supply of any country to the world market is linked to (i) the size of a country's national or domestic product and (ii) the size of a country's population.

6 These are the Pure Expenditure System Model (the simplest possible gravity-type model stems from a rearrangement of a Cobb-Douglas expenditure system implying identical expenditure shares and gravity equation income elasticity of unity) and the Trade-Share-Expenditure System Model (while a gravity equation is produced by such a framework, the real variables of interest are the non-income-dependent expenditure shares)
}

theoretically as a reduced form from a general equilibrium model of international trade in final goods. These authors also took into account the two main determinants that characterize models of the new theory of trade: economies of scale combined with the distinction of products, and transport costs.

Therefore, despite the theoretical controversies surrounding the model since its inception, the gravity model has proven to be the most accurate tool for the analysis and prediction of trade flows. When adapted to a panel data setting, this approach has a high explanatory power, increases the degrees of freedom, and also enables the proper specification of source and target country effects and time (business cycle) effects. Its empirical robustness has made it the "work-horse" baseline model for estimating the effects of geographical patterns of trade.

\section{Methodology and Data Framework}

\subsection{The Model}

In its basic form, the gravity model of bilateral trade hypothesizes that exports between two countries are proportional to their economic mass (measured by GDP and population size) and inversely proportional to the distance between them. Empirical works (Berstrand, 1985; Bougheas, Demetriades \& Morgenroth, 1999; Breuss \& Egger, 1999; Chen \& Wall, 1999; Egger, 2000; Helpman, 1987; Limao \& Venables, 1999; Matyas, 1997; Soloaga \& Winters, 1999; and Wei, 1996 among others) have provided a number of alternative specifications for the gravity model. In the context of international trade, the basic formulation of the gravity model is as follows:

$$
X_{i j t}=\beta_{0} Y_{i t}^{\beta_{1}} Y_{j t}^{\beta_{2}} N_{i t}^{\beta_{3}} N_{j t}^{\beta_{4}} D_{i j}^{\beta_{5}} U_{i j t}
$$

Trade theories based on imperfect competition and the Hecksher-Ohlin models justify the inclusion of only the core variables; namely income, population and distance. However, additional variables can be incorporated into the gravity equation to control for differences in geographical factors, historical ties and the overall trade policy for the fact that export flows between nations can be affected by factors besides the core variables. There is no universal agreement on which variables to include in the gravity equation beyond the core factors. Hence, the basic gravity model can be expanded by adding other variables, which are thought to explain the impact of various policy issues on export flows.

When gravity equations are used to estimate the effect of regional economic integration, dummy variables are added for the regional trade agreement under study. In addition, to avoid capturing the impact of other influences on exports, other dummy variables are added to control for common language and common border. Thus, by introducing these variables into Equation 3.4, the augmented gravity model becomes;

$$
\begin{aligned}
& X_{i j t}=\beta_{0} Y_{i t}^{\beta_{1}} Y_{j t}^{\beta_{2}} G D P P C_{i t}^{\beta_{3}} G D P P C_{j t}^{\beta_{4}} G D P P C D I F_{i j t}^{\beta_{5}} \\
& D_{i j}^{\beta_{6}} I_{i j}^{\beta_{i t}} I_{j t}^{\beta_{8}} \beta_{9} \text { Language }_{i j} \beta_{10} \text { Border }_{i j} \beta_{11} \text { comesa }_{i j t}
\end{aligned}
$$


For estimation purposes, the gravity model is most often used in its log-linear form. Hence, Equation 3.5 can be equivalently written using natural logarithms as:

$$
\begin{aligned}
& \ln X_{i j t}=\ln \beta_{0}+\beta_{1} \ln Y_{i t}+\beta_{2} \ln Y_{j t}+\beta_{3} \ln G D P P C_{i t} \\
& +\beta_{4} \ln G D P P C_{j t}+\beta_{5} \ln G D P P C D I F_{i j t}+\beta_{6} \ln D_{i j} \\
& +\beta_{7} \ln I F_{i t}+\beta_{8} \ln I F_{j t}+\beta_{9} \text { Language }_{i j}+\beta_{10} \text { Border }_{i j} \\
& +\beta_{11} \text { comesa } U_{i j t}
\end{aligned}
$$

From Equation 3.6, $G D P P C_{i t}$ is GDP per capita income of the exporting country at time $t, G D P P C_{j t}$ is GDP per capita income of the importing country at time $t, G D P P C D I F_{i j t}$ is the absolute value of the per capita GDP difference between countries $i$ and $j$ at time $t, I F_{i(j)}$ is the level of infrastructure development of trading nations at time $t$, Language $_{i j}$ is a dummy that takes value 1 if countries $i$ and $j$ share an official common language and zero otherwise, Border $_{i j}$ is a dummy that takes value 1 if countries $i$ and $j$ share a land border and zero otherwise, comesa is a dummy that takes value 1 for the period after formation of comesa (1994-2012) and zero otherwise, while $U_{i j t}$ is a stochastic error term. Below is an explanation of how each of the above factors was expected to affect exports in the COMESA regional trading bloc:

GDP is included in the model to capture the factors associated with the level of economic development (Frankel, 1997). Economies with higher GDP are expected to trade more than those with lower GDP because, the former tend to innovate more and have more advanced infrastructures that facilitate trade. It also captures the productive capacity of the exporting country and the purchasing power of the importing country. A higher GDP signifies greater potential supply from the exporting country and increased demand in the importing country. Therefore, the coefficients of the GDP variables were expected to be positive.

GDP per capita income has been incorporated in the model rather than population as has been the case in most previous gravity models. The main argument is that what matters more in trade is not the size of the population per se, but effective demand which can appropriately be measured by the GDP per capita. GDP per capita income of a country may affect trade in two different ways. A large GDP per capita income may indicate a large domestic market, high level of self sufficiency and less need for trade. However, a large GDP per capita income may promote economies of scale in production hence promoting the desire to trade in a greater variety of goods. Thus, the estimated coefficient for the GDP per capita income could be positive or negative.

The absolute difference in per capita income $\left(G D P P C D I F_{i j t}\right)$ has been added to the model to capture technology differences between countries in explaining trade patterns. Two hypotheses exist on the effect of this variable on trade. The first is the Linder hypothesis which posits that countries with similar levels of per capita income will have similar tastes, they will produce similar but differentiated products and trade more among themselves. The second is the Heckscher-Ohlin hypothesis which suggests that GDP per capita differences are highly correlated with differences in factor endowments and hence smaller differences could reduce trade, especially comparative advantage driven intra-industry trade. Therefore, the effect of this variable may either be positive or negative. A negative sign would support the Linder hypothesis, while a positive sign supports the Heckscher-Ohlin hypothesis.

The infrastructure variable measures the level of infrastructure development in the country. This variable takes into account the quality of trade and transport-related infrastructure such as ports, railroads, roads and information technology. More developed infrastructure is supposed to foster the movement of bilateral exports. Limão and Venables (2001) show that infrastructure is quantitatively important in determining transport costs. They estimate that poor infrastructure accounts for 40 percent of predicted transport costs for coastal countries and up to 60 percent for landlocked countries. Therefore, the coefficient estimates for the variables $I F_{i t}$ and $I F_{j t}$ were expected to be positive.

Sharing a common language can enhance export flows between countries by facilitating communication. Ease of communication facilitates foreign trade through translation as well as through the ability to communicate directly (Melitz, 2007). Linguistic links and other historical and cultural links are particularly important at reducing the cost of unfamiliarity in international trade, or what Linnemann (1966) called psychic costs, and Garnaut (1994) subjective resistance. Therefore, the estimated coefficient for this variable was expected to have a positive sign.

Sharing a common geographical frontier is expected to promote bilateral trade. The immediate consequence of geographical proximity is reduction in transport costs, short delivery time, less interest payments on export credits and low spoilage (Ekanayake, Mukherjee and Veeramacheneni, 2010). Near the border, consumers find it easy to cross over to shop in the other country and firms can source intermediate inputs in the other country, much more readily than would be possible if the countries did not share a common border. Therefore, the estimated coefficient of the variable Border $_{i j}$ was expected to have a positive sign.

The variable comesa is a dummy variable that takes the value 1 for the period after formation of COMESA (1994-2012) and zero otherwise, capturing the effect of COMESA on intra-regional export flows. Regional integration is expected to promote intra-regional exports. Therefore, the estimated coefficient of this variable was expected to have a positive sign. A positive value would imply that the formation of COMESA increased export flows among COMESA member countries, and vice versa.

The distance variable measures the physical distance between the economic centres of the trading partners. In measuring distance, sometimes authors locate countries at their geographical center, capital city or most populous city (Melitz, 2007). This study used distances measured from capital cities. Distance is a proxy for transportation costs. The greater the distance, the higher the transportation costs. Three kinds of costs are associated with doing business at a distance: 
(i) physical shipping costs, (ii) time-related costs and (iii) costs of (cultural) unfamiliarity (Rahman, 2009). Transportation costs raise the price of a good in the importing country, thus reducing its demand. Therefore, distance was expected to have a negative effect on exports.

It should be noted that the empirical model for the present study differs in some respects from the previous gravity models found in the literature. The major difference stems from the variables used in the model. Besides the core variables of the gravity model, this study adopted local variables that are believed to influence exports in the COMESA region. For example, GDP per capita has been used instead of population. Other explanatory variables that have been introduced in the model include; GDP per capita difference, infrastructure level, official common language and contiguity.

\subsection{Data Type and Sources}

The study used annual panel data on COMESA member countries and their trading partners for the period 1980 to 2012 The use of panel data helps to capture the relevant relationships among variables over time, reduces the collinearity among the explanatory variables, improves efficiency of econometric estimates, and controls for unobservable individual heterogeneity and dynamics (Baltagi, 2005). If individual effects are correlated with the regressors, OLS estimates omitting individual effects will be biased. Therefore, this study used panel data estimation for the empirical gravity model of trade.

The dependent variable used in the analysis was exports in USA dollars from country $i$ to country $j$. The data on exports were generated from the IMF Direction of Trade Statistics and the UN Commodity Trade Statistics (UN Comtrade) databases. Information on GDP in USA dollars was obtained from the World Development Indicators databases of the World Bank, the UNCTAD, Handbook of Statistics 2013 database and from International Monetary Fund, World Economic Outlook database, 2013. Data on GDP per capita in USA dollars were from the International Monetary Fund, World Economic Outlook database, 2013. Distance in kilometres was obtained from www.indo.com/distance/index.html (2013) ${ }^{7}$. Common language and common border were available in the World Fact Book 2013. Infrustructure levels for various countries, measured by the Logistics Performance Indices, were available http://data.worldbank.org/indicator/LP.LPI.INFR.XQ (2013) ${ }^{8}$.

\footnotetext{
7 This service uses data from the US Census and a supplementary list of cities around the world to find the latitude and longitude of two places, and then calculates the distance between them in kilometers (in a straight line).

8 Data are from Logistics Performance Index surveys conducted by the World Bank in partnership with academic and international institutions and private companies and individuals engaged in international logistics. Respondents evaluated the quality of trade and transport related infrastructure (e.g. ports, railroads, roads, information technology), on a rating ranging from 1 (very low) to 5 (very high). Scores are averaged across all respondents.
}

\section{Empirical Results and Discussion}

\subsection{Diagnostic Tests}

The gravity model (Equation 3.6) was first estimated using fixed effects regression and random effects regression (see results in Appendices A4.1 and A4.2 respectively). The hausman test was then applied to check whether the fixed effects model was more efficient than the random effects model. This would be true if the null hypothesis of no correlation between the individual effects and the regressors was rejected (see results in Appendix A4.3).

The Hausman test statistic shows that the null hypothesis was rejected, suggesting that the fixed effects (within) regression was more efficient than the random effects regression. However, following Martinez-Zarzoso and Nowak-Lehmann (2003), time-invariant variables in the gravity model (such as distance, common language and common border) cannot be directly estimated with a fixed effects model because the inherent transformation wipes out such variables. Hence, the instrumental variables Generalized Method of Moments (GMM) regression was applied. The instrumental variables GMM regression is an efficient estimator of panel data models. It provides consistent estimates, addresses the endogeneity problem, and allows for efficient estimation in the presence of heteroskedasticity (Baum, Schaffer \& Stillman, 2003).

\subsection{Estimation Results and Discussion}

Table 4.1. Empirical Results.

Dependent variable: Exports

\begin{tabular}{llll}
\hline Variable & \multicolumn{2}{l}{ Fixed Effects Random Effects } & GMM \\
\hline Exporter's GDP & 1.488 & 0.731 & 1.402 \\
& $(0.503)^{* * *}$ & $(0.048)^{* * *}$ & $(0.068)^{* * *}$ \\
Exporter's GDP per capita & -0.913 & -0.431 & -0.409 \\
& $(0.596)^{* *}$ & $(0.190)^{* *}$ & $(0.20)^{* *}$ \\
Importer's GDP per capita & 0.220 & 0.31 & 0.307 \\
& $(0.112)^{* *}$ & $(0.121)^{* * *}$ & $(0.122)^{* *}$ \\
GDP per capita difference & 0.225 & 0.295 & 0.281 \\
& $(0.090)^{* * *}$ & $(0.095)^{* * *}$ & $(0.101)^{* * *}$ \\
Distance & & -1.745 & -1.732 \\
& & $(0.111)^{* * *}$ & $(0.123)^{* * *}$ \\
Exporter's Infrastructure level & 0.776 & 0.007 & 0.662 \\
& $(0.039)^{* *}$ & $(0.016)^{* *}$ & $(0.042)^{* * *}$ \\
Importer's Infrastructure level & 0.778 & 0.337 & 0.668 \\
& $(0.037)^{* *}$ & $(0.157)^{* *}$ & $(0.040)^{* * *}$ \\
Common Official language & & 0.611 & 0.593 \\
& & $(0.235)^{* * *}$ & $(0.226)^{* * *}$ \\
Common border & & 1.085 & 1.104 \\
Comesa & & $(0.232)^{* * *}$ & $(0.255)^{* * *}$ \\
Constant & & 0.300 & 0.303 \\
R-Squared & 0.367 & $(0.146)^{* *}$ & $(0.143)^{* *}$ \\
Number of Observations & 1860 & 1.261 & 1.518 \\
Hausman test & $(0.217)^{* *}$ & 1.367 & 1.359 \\
\hline
\end{tabular}

Standard errors in parentheses.

$* * *, * *, *$ : statistically significant at $1 \%, 5 \%$ and $10 \%$ levels respectively.

Table 4.1 summarizes the empirical results obtained from 
estimating Equation 3.6, using fixed effects (within) regression, random effects GLS regression and instrumental variables GMM regression.

The effect of GDP of the exporting country was found to be positive and statistically significant at the 1 percent level of significance in all estimated models, which is in line with theoretical expectation. This result suggests that, in the COMESA region, GDP of a country is a key determinant of the country's capacity to export. A higher GDP means a higher production capacity which in turn translates into the ability of the economy to export more (supply side). This is consistent with the findings of Carrillo and Lee (2002).

The effect of GDP per capita income of the importing country was found to be positive and statistically significant at 5 percent level in all estimated models. This result suggests that a higher GDP per capita income for a trading partner country means a higher absorption capacity, implying that the trading partner country is able to import more (demand side). This is consistent with the findings of Achay (2006). This author investigated the determinants of trade flows between various countries of the world. He applied the gravity model on a sample of 146 countries for five-year sub-periods between 1970 and 2000. According to the study results, the exporter's GDP per capita had a positive impact on the volume of bilateral trade.

The effect of GDP per capita income difference was found to be positive and statistically significant at the 1 percent level of significance in all estimated models. Its positive sign suggests that bilateral trade flows between COMESA member countries are related positively to inter-country differences in the level of technological advancement. Large technological differences tend to promote bilateral trade between COMESA member countries. Therefore, the Heckscher-Ohlin hypothesis was found to be valid in the COMESA trading bloc. This result is consistent with the findings of Carrillo and $\mathrm{Li}$ (2002).

The effect of infrastructure in both the exporting and importing countries was found to be positive and statistically significant in all estimated models, which is consistent with $a$ priori expectation. Therefore, investment in transportation services and infrastructure is expected to promote exports in the COMESA trading bloc by reducing transport costs. Limao and Venables (2001) stressed the importance of investment in infrastructure as a way to reduce transport costs and promote trade. Using an upper limit Tobit, they found that improving the transport infrastructure considerably reduced cost, insurance and freight (CIF)/free on board (FOB) factor and hence had a significant impact on bilateral volumes of trade. Similar results were supported by Francois and Manchin (2006).

The effect of official common language was found to be positive and statistically significant in the random effects and GMM models, which is in line with the predicted theory. Sharing of an official common language promotes bilateral trade between the COMESA trading partners. Melitz (2007) posits that the absence of a common language and the consequent presence of linguistic barriers can be a major obstacle to foreign trade. This result is consistent with the previous findings of Achay (2006), Eita and Jordaan (2007),
Foroutan and Lant (1993), Martinez-Zarzoso and Nowak-Lehmann (2003) and Ram and Prasad (2000). In their empirical studies, these authors found a strong positive effect of the language variable and concluded that historical, cultural and colonial ties had a significant impact on the pattern of trade in their study samples.

The effect of common border was found to be statistically significant at the 1 percent level of significance in the random effects and GMM models and in line with the predicted theory. Sharing a common border facilitates trade. Thus, COMESA member countries with common frontiers tended to have more bilateral trade. This result is consistent with the findings of Carrillo and Li (2002) whose empirical study on regional integration schemes in Latin American showed that adjacency had a very strong effect on the bilateral volume of trade.

The regression results show that the effect of GDP per capita income of the exporting country was negative and statistically significant at the 5 percent level in all estimated models. This implies that a country with a high GDP per capita income would have a domestic market that is large enough to absorb a considerable share of domestically produced goods and thereby reducing the amount of goods that could be exported. In this case, an increase in the GDP per capita income of a COMESA member country raises the absorption capacity of the domestic market, resulting into lower exports. This result is consistent with the findings of Foroutan and Lant (1993). In a study on the effect of regional integration arrangements on trade in Sub-Saharan Africa, these authors found that a higher GDP per capita of an exporting country reduced the trade potential.

The effect of geographical distance was found to be negative and statistically significant at the 1 percent level in the random effects and GMM models, which is consistent with the theoretical expectation. These results provide strong support for the hypothesis that transportation costs are an important determinant of trade flows in the COMESA trading bloc. This implies that neighbouring COMESA countries, with low transportation costs between them, tended to trade more intensely among themselves than those that are further apart. This result is consistent with the findings of Achay (2006), Frankel (1997), Krugman (1991), among others. These authors assessed the role played by geographical proximity in the regionalisation process, and found that the geographical distance, among other factors, had a negative impact on the volume of trade in their study samples.

To assess the effect of COMESA on intra-regional exports, a comparison of the pre-COMESA period (1980-1993) with the post-COMESA period (1994-2012) was done through the introduction of a comesa dummy variable. The effect of this dummy variable was found to be positive and statistically significant at the 5 percent level of significance in all estimated models. This implies that the formation of COMESA had a positive effect on export flows in the COMESA trading bloc. Results from the GMM model show that intra-COMESA exports have grown by approximately 35 percent $\left[\left(\exp ^{0.3}-1\right) \times 100\right]$ since the formation of COMESA. This result suggests that the formation of COMESA has increased the propensity of COMESA member countries to 
trade with each other rather than with non-members. Similar studies have been done on other regional integration schemes. Chan-Hyun (2001), Martinez-Zarzoso and Nowak-Lehmann (2003) and Ram and Prasad (2000) found that regional integration had a positive and statistically significant effect on bilateral trade flows in their study samples.

But contrary to the a priori expectat, GDP of the importing country was found to be insignificant in all estimated models. This implies that the importer's GDP had no significant impact on exports in the COMESA RTA. This result suggests that a large GDP could indicate a high level of self sufficiency and less reliance on imports. Thus, while most empirical studies done on other regional trade blocs (Achay, 2006; Carrillo and Li, 2002; Ekanayake et al, 2010) found a positive effect of importer's GDP on exports, this study found no evidence to suggest that the importer's GDP had a significant effect on intra-COMESA exports.

\section{Summary and Policy Implications}

\subsection{Summary}

This paper has examined the effect of COMESA RTA on intra-regional exports. The study used panel data on COMESA member countries and their trading partners for the period 1980 to 2012 . An augmented trade gravity model was estimated using fixed effects (within) regression, random-effects GLS regression and instrumental variables GMM regression. The findings suggest that the formation of COMESA trading bloc has improved export performance among its member countries, implying intra-bloc export bias. The results from the instrumental variables GMM model show that intra-COMESA exports have grown by approximately 35 percent since the formation of COMESA. Exporter's GDP, importer's GDP per capita, per capita GDP difference between trading partners, infrastructure level, official common language, and contiguity had a positive and statistically significant effect on intra-COMESA export flows. On the other hand, exporter's GDP per capita and distance between trading partners had a negative and statistically significant effect on intra-COMESA export flows. Contrary to expectation, importer's GDP did not have any significant impact on intra-COMESA exports.

\subsection{Policy Implications}

The study has shown that regional economic integration had a significant positive effect on intra-COMESA exports. This result suggests that in order to enhance export flows in the COMESA region, the process of economic integration should be deepened. An important policy implication that comes out from the transport cost and adjacency variables is that investment in transport and communications infrastructure that reduces long distance cost of doing business would have a major impact in the integration of COMESA economies. This could be supplemented by the harmonization of customs procedures among COMESA member countries, elimination of non-tariff barriers to trade, establishing a common external tariff (CET) and promotion of value addition and regional value chains, among other policy interventions.

A4.1. Fixed Effects Model.

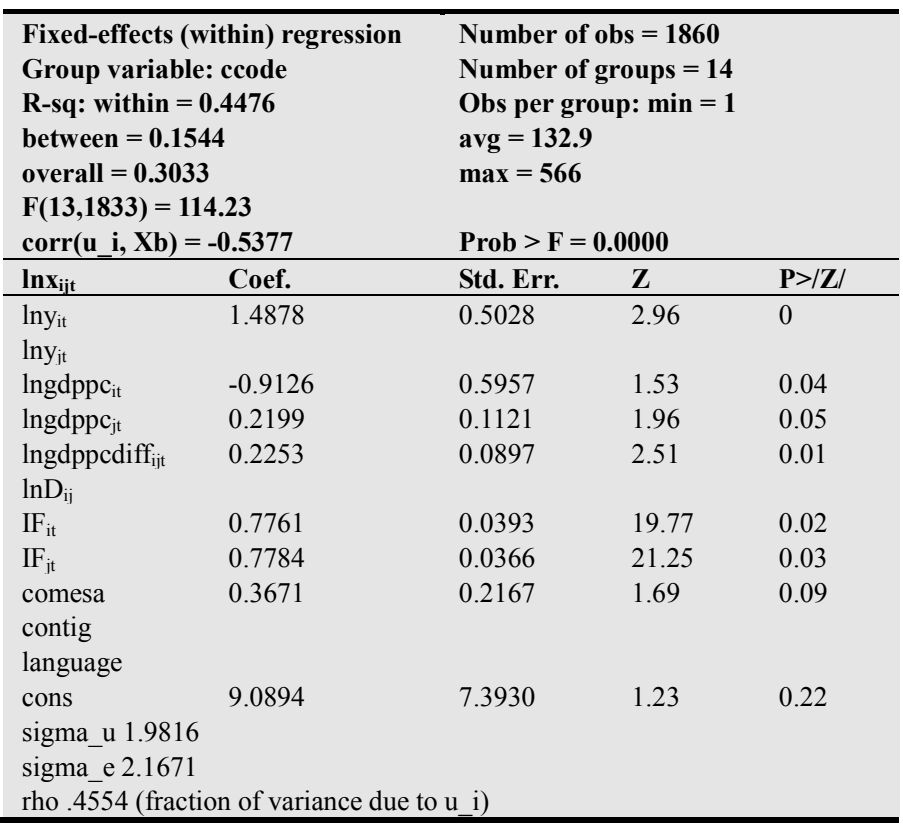

A4.2. Random Effects Model.

\begin{tabular}{|c|c|c|c|c|}
\hline \multicolumn{2}{|c|}{$\begin{array}{l}\text { Random-effects GLS regression } \\
\text { Group variable: ccode } \\
\text { R-sq: within }=0.4373 \\
\text { between }=0.1841 \\
\text { overall }=0.4205 \\
\text { Random effects } u_{\text {_ }} \mathbf{i} \sim \text { Gaussian } \\
\text { corr }(\mathbf{u} \mathbf{i}, \mathbf{X})=0 \text { (assumed) }\end{array}$} & \multicolumn{2}{|c|}{$\begin{array}{l}\text { Number of obs }=1860 \\
\text { Number of groups }=14 \\
\text { Obs per group: } \min =1 \\
\text { avg }=132.9 \\
\max =566 \\
\text { Wald chi2 }(13)=1339.53 \\
\text { Prob }>\operatorname{chi} 2=0.0000\end{array}$} & \multirow[b]{2}{*}{$\mathbf{P}>|\mathbf{z}|$} \\
\hline $\ln x_{i j t}$ & Coef. & Std. Err. & $\mathbf{z}$ & \\
\hline $\ln y_{i t}$ & 0.7310 & 0.0477 & 15.33 & 0 \\
\hline $\ln y_{\mathrm{jt}}$ & 0.6710 & 0.0391 & 17.17 & 0 \\
\hline $\operatorname{lngdppc} c_{i t}$ & -0.4313 & 0.1903 & -2.27 & 0.02 \\
\hline $\operatorname{lngdppc} c_{\mathrm{jt}}$ & 0.3100 & 0.1208 & 2.57 & 0.01 \\
\hline lngdppcdiff $f_{\mathrm{jit}}$ & 0.2950 & 0.0950 & 3.11 & 0 \\
\hline $\operatorname{lnD_{ij}}$ & -1.7469 & 0.1110 & -15.74 & 0 \\
\hline $\mathrm{IF}_{\mathrm{it}}$ & 0.0072 & 0.0156 & 0.46 & 0.02 \\
\hline $\mathrm{IF}_{\mathrm{jt}}$ & 0.3374 & 0.1566 & 2.15 & 0.03 \\
\hline comlangoff & 0.6110 & 0.2346 & 2.6 & 0 \\
\hline comesadummy & 0.2997 & 0.1458 & 2.05 & 0.04 \\
\hline Border & 1.0851 & 0.2324 & 4.67 & 0 \\
\hline $\begin{array}{l}\text { cons } \\
\text { sigma_u } 0.00 \\
\text { sigma_e } 2.1671 \\
\text { rho } 1.969 \mathrm{e}-07 \text { (f }\end{array}$ & tion of varianc & 1.3668 & 0.92 & 0.36 \\
\hline
\end{tabular}

A4.3. Hausman Test.

\begin{tabular}{lllll}
\hline Coefficients & & & & \\
\hline & $(\mathbf{b})$ & $(\mathbf{B})$ & (b-B) & sqrt(diag(V_b-V_B)) \\
\cline { 2 - 5 } & fixed & random & Difference & S.E. \\
\hline lny $_{\text {it }}$ & 1.4878 & 0.7310 & 0.7569 & 0.5006 \\
lngdppc $_{\text {it }}$ & 0.9126 & -0.4313 & 1.3439 & 0.5645 \\
lngdppc $_{\mathrm{jt}}$ & 0.2199 & 0.3100 & -0.0900 & \\
$\operatorname{lngdppcdiff}_{\mathrm{ijt}}$ & 0.2253 & 0.2950 & -0.0696 & \\
$\operatorname{lnD}_{\mathrm{ij}}$ & -1.9914 & -1.7468 & -0.2446 & \\
$\mathrm{IF}_{\mathrm{it}}$ & 0.3177 & 0.3374 & 0.3374 & \\
$\mathrm{IF}_{\mathrm{jt}}$ & 0.7510 & 0.7855 & -0.0345 & \\
comesadummy & 0.3671 & 0.2997 & 0.0674 & 0.1603 \\
\hline
\end{tabular}




\begin{tabular}{|c|c|c|c|c|}
\hline \multicolumn{5}{|l|}{ Coefficients } \\
\hline & (b) & (B) & (b-B) & sqrt(diag(V_b-V_B)) \\
\hline & fixed & random & Difference & S.E. \\
\hline contig & 1.1110 & 1.0851 & 0.0258 & 0.0075 \\
\hline Comlangoff & 0.4778 & 0.6110 & 0.6110 & -0.1332 \\
\hline \multicolumn{5}{|c|}{$\mathrm{b}=$ consistent under Ho and Ha; obtained from xtreg } \\
\hline \multicolumn{5}{|c|}{$\mathrm{B}=$ inconsistent under Ha, efficient under Ho; obtained from xtreg } \\
\hline \multirow{2}{*}{\multicolumn{5}{|c|}{$\begin{array}{l}\text { Test: Ho: difference in coefficients not systematic } \\
\text { chi2(10) }=(b-B)^{\prime}\left[\left(V_{b} \text { b-V } B\right)^{\wedge}(-1)\right](b-)=497.91\end{array}$}} \\
\hline & & & & \\
\hline \multicolumn{5}{|l|}{ Prob $>$ chi $2=0}$. \\
\hline \multicolumn{5}{|l|}{$(\mathrm{V} b-\mathrm{V}$ B is } \\
\hline
\end{tabular}

A4.4. The Augmented Gravity Model.

\begin{tabular}{|c|c|c|}
\hline Instrumental va & MM) regression & \multirow[t]{2}{*}{$\begin{array}{l}\text { Number of obs }=1860 \\
\text { Wald chi2 }(13)=1236.79 \\
\text { Prob }>\text { chi2 }=\mathbf{0 . 0 0 0 0} \\
\text { R-squared }=\mathbf{0 . 4 2 0 5} \\
\text { Root MSE }=\mathbf{2 . 3 5 2 7} \\
\text { Std. Err. }\end{array}$} \\
\hline $\ln x_{i t}$ & Coef. & \\
\hline $\begin{array}{l}\ln Y_{\text {it }} \\
\ln Y_{\text {it }}\end{array}$ & $\begin{array}{l}1.40233 \\
\text { (dropped) }\end{array}$ & $0.0680571^{* * *}$ \\
\hline $\operatorname{lnGDPPC}_{\mathrm{it}}$ & -0.4089703 & $0.1973408 * *$ \\
\hline $\operatorname{lnGDPPC}_{\mathrm{it}}$ & 0.3069759 & $0.121926^{* *}$ \\
\hline $\operatorname{lnGDPPCDIF}{ }_{\mathrm{ijt}}$ & 0.2810688 & $0.1014765 * * *$ \\
\hline $\operatorname{lnD_{ij}}$ & -1.731926 & $0.1232024 * * *$ \\
\hline $\ln I F_{i t}$ & 0.6617 & $0.0416 * * *$ \\
\hline $\operatorname{lnIF} \mathrm{jt}_{\mathrm{jt}}$ & 0.6681 & $0.0397 * * *$ \\
\hline Comesadummy & 0.3033965 & $0.1432695 * *$ \\
\hline Border $_{i j}$ & 1.104427 & $0.2555312 * * *$ \\
\hline Language $_{i j}$ & 0.5929896 & $0.2264269 * * *$ \\
\hline cons & 1.518267 & 1.359402 \\
\hline
\end{tabular}

$* * *, * *, *$ : statistically significant at $1 \%, 5 \%$ and $10 \%$ levels respectively.

\section{References}

[1] Achay, L. (2006). Assessing Regional Integration in North Africa. National Institute of Statistics and Applied economics, Rabat, Morocco.

[2] African Union. (2012). Action Plan for Boosting Intra-African Trade. Synthesis Paper on Boosting Intra-African Trade and Fast Tracking the Continental Free Trade Area, 25 Jan 2012, Addis Ababa, Ethiopia.

[3] Ajayi, K. (2005). Regional Financial and Economic Integration in West Africa. Department of Economics, Stanford University, Stanford, CA 94309.

[4] Anderson, J. E. (1979). A Theoretical Foundation for the Gravity Equation. American Economic Review, 69(1), 106-116.

[5] Anderson, J. E. and van Wincoop, E. (2003). Gravity with Gravitas: A Solution to the Border Puzzle. American Economic Review, 93(1), 170-192.

[6] Avom, D. (2005). Les déterminants des échanges dans la CEMAC: Une évaluation empirique. Economie Appliquée, $\operatorname{LVIII}(2), 127-53$.

[7] Balassa, B. (1975). Economic Integration among Developing Countries. Journal of Common Market Studies, September 1975.

[8] Baldwin, R. E. and Seghezza, E. (1996a). Trade-Induced Investment-Led Growth. NBER Working Paper No. 5582, Cambridge, Massachusetts.
[9] Baltagi, B. (2005). Econometric Analysis of Panel Data. Third edition. Wiley.

[10] Baum, C.F., Schaffer, M.E. and Stillman, S. (2003). Instrumental Variables and GMM: Estimation and Testing. The Stata Journal, 3, 1-31. Working paper version: Boston College Department of Economics Working Paper No 545.

[11] Bergstrand, J.H. (1985). The Gravity Equation in International Trade: Some Microeconomic Foundations and Empirical Evidence. The Review of Economics and Statistics, 67, 474-481.

[12] Bergstrand, J.H. (1989). The Generalized Gravity Equation, Monopolistic Competition, and the Factor-Proportions Theory in International Trade. The Review of Economics and Statistics, $71,143-153$.

[13] Bougheas, S., Demetriades, P. and Morgenroth, E. (1999). Infrastructure, Transport Costs and Trade. Journal of International Economics, 47(1), 169-189.

[14] Breuss, F. and Egger, P. (1999). How Reliable are Estimations of East-West Trade Potentials based on Cross-Section Gravity Analyses? Empirica 26 (2), 81-95.

[15] Carrère, C. (2004). African Regional Agreements: Impact on Trade with or without Currency Unions. Journal of African Economies, 13(2), 199-239.

[16] Carrillo, C. and Li, C. A. (2002). Trade Blocks and the Gravity Model: Evidence from Latin American Countries. Working Paper, Department of Economics, University of Essex, UK.

[17] Carrillo-Tudela, C. and Li, C. A. (2004). Trade Blocks and the Gravity Model: Evidence from Latin American Countries. Journal of Economic Integration, 19(4), 667-89.

[18] Chan-Hyun, S. (2001). A Gravity Model Analysis of Korea's Trade Patterns and the effects of a Regional Trade Agreement. International Centre for the study of East Asia Development, Kitakyushu. Working Paper Series 2001-09, 1-35.

[19] Chen, I-H. and Wall H. J. (1999). Controlling for Heterogeneity in gravity models of Trade. Federal Reserve Bank of St. Louis Working Paper 99-010A.

[20] Clarete, R., Edmonds, C. and Wallack, J.S. (2002). Asian Regionalism and its Effects on Trade in the 1980s and 1990s. Journal of Asian Economics, 14, 91-129

[21] COMESA. (2011). Progress Report for 2012. COMESA Secretariat, Lusaka, Zambia.

[22] COMESA Treaty, 1993 is available at http://www.comesa.int viewed on $18 / 12 / 2012$.

[23] Deardorff, A.V. (1998). Determinants of Bilateral Trade: Does Gravity Work in a Neoclassical World? in J. Frankel (ed), The Regionalization of the World Economy, NBER, 7-22.

[24] Egger, P. (2000). A Note on the Proper Econometric Specification of the Gravity Equation. Economic Letters, 66, 25-31.

[25] Eita, H.J. and Jordaan, A.C. (2007). South Africa's Wood Export Potential Using a Gravity Model Approach. University of Pretoria, Working Paper 2007-23, 1-24.

[26] Ekanayake, E. M., Mukherjee, A. and Veeramacheneni, B. (2010). Trade Blocks and the Gravity Model: A Study of Economic Integration among Asian Developing Countries. Journal of Economic Integration, 25(4), 627-643. 
[27] Elbadawi, I.A. (1995). The Impact of Regional Trade Monetary Schemes on Intra-Sub Saharan Trade. AERC, Harare.

[28] Evenett, S.J. and Keller, W. (1998). On the Theories Explaining the Success of the Gravity Equation, in NBER Working Paper No. 6529, Cambridge, MA: National Bureau of Economic Research.

[29] Fouratan, F. (1992). The Regional Integration in Sub-Saharan Africa: Past Experiences and Future Prospects. Policy Research Working Paper WPS 1992, The World Bank, Washington D.C.

[30] Foroutan, F. and Lant, P. (1993). Intra-Sub-Saharan African Trade: Is it Too Little? Journal of African Economies, 2(1), 74-105.

[31] Francois, J. and Manchin, M. (2006). Institutional Quality, Infrastructure, and the Propensity to Export. Department of Economics, Universit'a degli Studi di Milano, Via Conservatorio 7, 20122 Milano, Italy.

[32] Frank, I. (1978). Reciprocity and Trade Policy for Developing Countries. Finance and Development, Vol. 15, No. 1.

[33] Frankel, J. (1997). Regional Trading Blocs and the World Economic System. Institute for International Economics, Washington D.C.

[34] Garnaut, R. (1994). Open Regionalism: Its Analytic Basis and Relevance to the International System. Journal of Asian Economics, 5(2), 273-90.

[35] Helpman, E. (1987). Imperfect Competition and International Trade: Evidence from Fourteen Industrial Countries. Journal of the Japanese and International Economies, 1(1), 62-81.

[36] Helpman, E. and Krugman, P. (1985). Market Structure and Foreign Trade: Increasing Returns, Imperfect Competition and International Economy. Cambridge, MA, MIT Press.

[37] Henrekson, M., Torstensson, J. and Torstensson (Currently Gustavsson), R. (1997). Growth Effects of European Integration. European Economic Review, 41(8), 1537-1557.

[38] Jebuni, C. (1997). Trade Liberalization and Regional Integration in Africa, in A. Oyejide, I. Elbadawi and P. Collier (eds), Regional Integration and Trade Liberalization in Sub-Saharan Africa, Vol. 1, "Framework, Issues and Methodological Perspectives", New York: St. Martin's Press.

[39] Kagira, B.M. (2001). The Effects of Regional Integration on the Performance of Intra-Industry Trade in Eastern and Southern Africa. The COMESA Centre, Lusaka, Zambia and Manchester, Manchester University Press.

[40] Kritzinger-van N. L. (2005). Regional Integration: Concepts, Advantages, Disadvantages and Lessons of Experience. World Bank Discussion Paper, South Africa Country Office.

[41] Krugman P. (1991a). Increasing returns and economic geography. Journal of Political Economy 99, 483-499.

[42] Limão, N. and Venables, A. J. (1999). Infrastructure, Geographical Disadvantage and Transport Costs. Policy Research Working Paper 2257, World Bank.

[43] Limão, N. and Venables, A. J. (2001), Infrastructure, Geographical Disadvantage, Transport Costs, and Trade. The World Bank Economic Review, 15(3), 451479.

[44] Linnemann, H. (1966). An Econometric Study of International
Trade Flows. Amsterdam, Holland.

[45] Longo, R. and Sekkat, K. (2004). Economic Obstacles to expand Intra-African Trade. World Development, 32(8), 1309-1323.

[46] Martinez-Zarzoso, I. \& Nowak-Lehmann, F. (2003). Augmented Gravity Model: An Empirical Application to Mercosur-European Union Trade Flows. Journal of Applied Economics, 6(2), 291-316.

[47] Mátyás, L. (1997). Proper Econometric Specification of the Gravity Model. The World Economy, 20(3), 363-368.

[48] Melitz, J. (2007). North, South and Distance in the Gravity Model. European Economic Review, 51, 971-991, London, UK.

[49] Morrison, T. K. (1976). Manufactured Exports and Protection in Developing Countries: A Cross-Country Analysis. Economic Development and Cultural Change, 25(1), 151-58.

[50] Musila, J.W. (2005). The Intensity of Trade Creation and Trade Diversion in COMESA, ECCAS and ECOWAS: A Comparative Analysis. Journal of African Economies, 14(1), $117-41$.

[51] Pöyhönen, P. (1963). A Tentative Model for the Volume of Trade between Countries. Weltwirtschaftliches Archiv, 90(1), 93-100.

[52] Rahman, M.M. (2009). Australia's Global Trade Potential: Evidence from the Gravity Model Analysis. In: Oxford Business and Economics Conference, 24-26 June, 2009, Oxford University, Oxford, UK.

[53] Ram, Y. and Prasad, B. (2000). Assessing Fiji's Global Trade Potential using the Gravity Model Approach. Fiji, University of South Pacific.

[54] Robson, P. (1998). The Economics of International Integration, $4^{\text {th }}$ edition, London: Routledge.

[55] Smith, A. (1776). An Inquiry into the Nature and Causes of the Wealth of Nations. Reprinted in 1976. Chicago: University of Chicago Press.

[56] Soloaga, I. and Winters, A. (1999). Regionalism in the Nineties: What effects on trade? Development Economic Group of the World Bank, mimeo.

[57] Tinbergen, J. (1962). Shaping the World Economy: Suggestions for an International Economic Policy. New York: The Twentieth Century Fund.

[58] UNCTAD. (2009). Economic Development in Africa: Strengthening Regional Economic Integration for Africa's Development. United Nations; New York and Geneva, UNCTAD/ALDC/AFRICA/2009.

[59] Viner, J. (1950). The Customs Union Issue. Carnegie Endowment for International Peace, New York.

[60] Wei, S.J. (1996). Intra-National versus International Trade: How Stubborn are Nations in Global Integration? NBER, Working Paper 5531.

[61] World Bank. (2013). World Development Indicators. Washington, D.C.

Yang, Y. and Gupta, S. (2005). Regional Trade Arrangements in Africa: Past Performance and the Way Forward. IMF Working Paper 05/36, IMF, Washington D.C. 